\title{
Wet Cupping Therapy Improves Health Related Quality of Life: A Self-Controlled Interventional Study
}

\section{Hacamat Sağlıkla İlgili Yaşam Kalitesini Arttırmakta: Kendinden Kontrollü Girişimsel Çalışma}

\author{
Süleyman Ersoy'1, Habibe İnci², Didem Sunay², Seyit Ali Kayıs³, Velittin Selçuk Engin ${ }^{4}$, \\ Ali Ramazan Benli² \\ 'Sağlık Bilimleri Üniversitesi Ümraniye EAH Aile Hekimliği Kliniği \\ ${ }^{2}$ Karabük Üniversitesi Tıp Fakültesi Aile Hekimliği Anabilim Dalı \\ 3Karabük Üniversitesi Tıp Fakültesi Biyoistatistik Anabilim Dalı \\ ${ }^{4}$ Sağlık Bakanlığı Fatih Melekhatun ASM
}

\begin{abstract}
Objectives: Wet cupping therapy is an ancient treatment method which has been an integral part of Traditional Anatolian Medicine. In the current study we aimed to assess the efficacy of wet cupping therapy on health-related quality of life in healthy volunteers.

Materials and Methods: This was a single arm pre-test and post-test interventional study conducted in Traditional and Complementary Medicine Clinic of Karabuk Education and Research Hospital between August 1, 2017 and August 1, 2018. Fifty-three healthy volunteers were enrolled in the study. They received three wet cupping therapy sessions once every month for three months (On o, 30, and 60 days). WHOQOL-BREF-TR questionnaire was applied to all participants both before the sessions and after the third one. Wilcoxon signed rank test was employed to compare pre and post test scores. A p value $<0.05$ assumed to be statistically significant. All analyzes were carried out using Minitab 17 Statistical Software.

Results: The study sample consisted of 26 female and 27 male subjects. Mean age was $43.68 \pm 9.41$ years. It was found $46.34 \pm 9.78$ years for females and $40.63 \pm 8.43$ years for males. Initial WHOQOLBREF-TR scores regarding general health $(p<0.001)$ and the four domains which were physical $(p<0.001)$, psychological $(p<0.001)$, social relations $(p<0.001)$ and the environmental domain $(p<0.005)$ showed significant improvements after three WCT sessions

Conclusion: Our results suggest that quality of life may be improved in healthy adults by wet cupping therapy.

Key words: Wet cupping therapy, WHOQOL-BREF-TR, Quality of life
\end{abstract}

\section{$\ddot{O} \mathbf{z}$}

Amaç: Geleneksel Anadolu Tıbbına ait bir uygulama olarak bilinen hacamat kadim tedavi metotlarından biridir. Bu çalışmada hacamat uygulamasının sağlıklı gönüllülerde yaşam kalitesi üzerine olan etkisini araștırdık.

Materyal ve Metot: Tek kol, test öncesi ve sonrası girişimsel bir çalışma olarak planlanan araștırmamız 1 Ağustos 2017 ve 1 Ağustos 2018 tarihleri arasında Karabük Eğitim ve Araștırma Hastanesi Geleneksel ve Tamamlayıcı Tıp Merkezinde gerçekleștirildi. Çalışmaya 53 sağlıklı gönüllü iştirak etti. Katılımcıların her birine ayda bir kez olmak üzere toplamda üçer kez hacamat uygulandı. Ayrıca gönüllülerin tümüne WHOQOL-BREF-TR ölçeği hacamat uygulamalarının öncesi ve üçüncü uygulamayı takiben olmak üzere iki kez uygulandı. Elde edilen skorların karşılaştırılmasında Wilcoxon signed rank test kullanıldı ve $\mathrm{p}<0.05$ değeri anlamlı kabul edildi. İstatistiksel hesaplamalar Minitab 17 Statistical Software kullanılarak yapildı.

Bulgular: 26 kadın ve 27 erkek gönüllünün katıldığı çalışmada yaş ortalaması 43,68 \pm 9,41 yıl bulundu. Yaş ortalaması kadınlarda 46,34 \pm 9,78 iken erkeklerde 40,63 $\pm 8,43$ yıl bulundu. Uygulamalar öncesi ölçülen WHOQOL-BREF-TR skorlarını üç seans Hacamat uygulamasını takiben elde edilen skorlarla karşılaştırdığımızda; genel sağlı $(\mathrm{p}<\mathrm{0}, 001)$ ve fiziksel $(\mathrm{p}<0,001)$, psikolojik $(\mathrm{p}<0,001)$, sosyal ilişkiler $(\mathrm{p}<0,001)$ ve çevre $(\mathrm{p}=0,005)$ bașlıklarından oluşan 4 ana grubun tamamında yaşam kalitesinin anlamlı olarak arttığı gözlendi.

Sonuç: Çalışmamızda Hacamat tedavisinin sağlıklı bireylerde yaşam kalitesini arttırdığını gösterdik. Anahtar kelimeler: Hacamat, WHOQOL-BREF-TR, Yașam kalitesi 
Yazışma Adresi / Correspondence:

Dr. Süleyman Ersoy

e-mail: suleymanersoy@gmail.com

Date of submission: 28.03.2019

Date of admission: 13.06.2019

\section{Introduction}

Recent decades witnessed an increased global interest on traditional and complimentary medical applications. In line with the World Health Organization's (WHO) efforts of adjusting Traditional and Complimentary Medicine (TCM) to current medicine, Turkish Health Ministry (THM) issued a series of regulations to prove TCM applications were implemented in concert with Good Clinical Practice (GCP) and scientific criteria. Cupping therapy is among the TCM applications which were recognized and defined in terms of application and education principles by THM. It consists of two modalities as Dry Cupping and Wet Cupping Therapy (WCT). It's an integral part of the medicine that has been existed in Anatolia for millennia, even before Ottoman and Seljukian medicine and currently called Unanic medicine in literature. WCT was applied in Anatolia since ancient times not only for treatment, but also for health protection in certain periods observing lunar phases.

There are many studies in literature that examined the therapeutic effects of WCT in chronical headache, migraine, carpal tunnel syndrome, neck pain, brachialgia, low back pain and even hypertension. ${ }^{1-4}$ Yet, studies which assess its effects on healthy volunteers are scarce. In two of these studies which we cited, biochemical and hematologic parameters were assessed in blood specimens from healthy subjects. ${ }^{5,6}$

As far as we know, there are no studies investigating the effects of WCT on overall wellbeing in healthy volunteers. In our country, this therapeutic tool is used to protect overall health as a tradition. Examining the effects of WCT on health quality will be a significant contribution to existing knowledge about this application's effects on overall health.

In the current study we aimed to assess the efficacy of WCT on health-related quality of life (HRQOL) in healthy volunteers that were applied to TCM clinic of Karabuk Education and Research Hospital (KERH) by using the Turkish version of WHOQOLBREF scale which was developed by World Health Organization (WHO).

\section{Materials and Methods}

This was a single arm pre-test and post-test interventional study. Fifty-three healthy volunteers who were 18 to 60 years old and that were applied to TCM clinic of KERH for health protection between August 1, 2017 and August 1, 2018 were enrolled in the study. Exclusion criteria were any chronically disease, a complaint as a cause of WCT application, administration of WCT in the recent three months, routine use of any medicine, detected contraindication for WCT (i.e. Hemoglobin values below 9.5 gr/dl, INR below 1.5) during the initial routine evaluation.

\section{Ethics approval and informed consent}


All participants were included in the study after their informed consent was obtained. Ethical approval was obtained from Karabuk University Clinical Trials Ethics Committee (No:1/5; 09.01.2018). All procedures were in accordance with the ethical standards of the institutional and/or national research committee as well as 1964 Helsinki declaration and its later amendments or comparable ethical standards.

\section{WCT applications}

All patients received three WCT sessions once every month for three months (On o, 30, and 6o days). WCT was conducted using disposable vacuum cups on 5 acupuncture points: DU 14 (Dazhui) point on the posterior median line, in the depression below the processus spinosus of the 7 th cervical vertebra; UB 42 (Pohu) bilateral points on the back, 3.o cun lateral to the lower border of the spinous process of the 3 rd thoracic vertebra interscapulum region; and UB 46 (Geguan) bilateral points on the back, 3.0 cun lateral to the lower border of the spinous process of the 7 th thoracic vertebra. Each WCT procedure was performed by triple $S$ technique and in 3 phases:

Primary sucking: After disinfection of the selected regions with povidone iodine, the cup was placed on the selected site and the air was pressured out of the cup with manual suction. The cups were placed on the skin and kept on the skin for a period of 3 to 5 minutes.

Scarification: $2-3 \mathrm{~mm}$ deep and 3-5 $\mathrm{mm}$ long superficial incisions were made on the skin with a No. 11 sterile surgical blade.

Secondary sucking and blood-letting: The cups were located on the skin in the manner described above again and left at the application site until filled with the blood from the capillary.

At the end of the WCT procedure, the cups filled with blood were removed and destroyed in medical waste. A sterile sponge dressing was applied.

WHOQOL-BREF-TR questionnaire was applied to all participants both before the WCT sessions and after the third one. WHOQOL-BREF is the short form of a 1oo-items questionnaire called WHOQOL-100, which has been developed by WHO to evaluate health quality. It consists of four main domains as physical and psychological wellbeing, social relationships and environment. It also includes a division to assess overall health and quality of life. While the latter includes only two questions, the remaining 24 questions are related to each of the domains mentioned above. The score of each domain was calculated by summing the points which can be 1 to 5 according to the answer to each question. ${ }^{7}$

WHOQOL-BREF-TR 27 is consisted of 27 questions. It was developed by Eser and colleagues in 1999 adding one more question while the validity and reliability studies of the 26 -items form in Turkish subjects. ${ }^{8}$

\section{Statistical Analysis}

Distributional properties of the data were examined using Anderson-Darling normality test. Descriptive statistics were obtained for demographic features of the participants. Normally distributed data was presented as mean \pm sd, while non-normally distributed data presented as median (min. - max.). Counted data for categorical variables were presented as percentage. Wilcoxon signed rank test was employed to compare pre and 
post test scores. A p value $<0.05$ assumed to be statistically significant. All analyzes were carried out using Minitab 17 Statistical Software. 9

\section{Results}

The study sample consisted of 26 female and 27 male subjects. Mean age was $43.68 \pm$ 9.41 while youngest subject was 18 ; oldest one was 56 years old. Mean age was found $46.34 \pm 9.78$ years for females and $40.63 \pm 8.43$ years for males Demographic features of the participants were expressed in Table 1.

Table 1: Demographic features of the participants

\begin{tabular}{|l|c|}
\hline Variable & Participants $(\mathbf{N}=\mathbf{5 3})$ \\
\hline Age (years) & $43.68 \pm 9.41$ \\
\hline \multirow{2}{*}{ Gender } & Male $(51 \%)$ \\
\hline \multirow{2}{*}{ Education } & Female (49\%) \\
& Primary (34\%) \\
\hline \multirow{2}{*}{ Marital Status } & Secondary (41\%) \\
\hline \multirow{2}{*}{ Smoking } & University (25\%) \\
& Married $(94 \%)$ \\
& Single (6\%) \\
\hline
\end{tabular}

As shown in Tables 2 to 4, initial WHOQOL-BREF-TR scores regarding general health and the four domains $(p<0.001)$ including the environmental domain $(p<0.005)$ showed significant improvements after three WCT sessions. General health scores improved significantly after interventions overall and in subgroups (Table 2).

Table 2: Changes in general health scores before and after WCT application

\begin{tabular}{|c|c|c|c|c|}
\hline \multirow{3}{*}{ Overall } & & Pre-test & Post-test & \multirow{2}{*}{$\mathbf{P}^{*}$} \\
\hline & $\mathbf{n}$ & Median (min-max) & Median (min-max) & \\
\hline & 53 & $5(2-7)$ & $8(2-10)$ & $<0.001$ \\
\hline \multicolumn{5}{|l|}{ Gender } \\
\hline Male & 27 & $12(5-16)$ & $17(9-19)$ & $<0.001$ \\
\hline Female & 26 & $6(2-7)$ & $8(4-10)$ & $<0.001$ \\
\hline \multicolumn{5}{|l|}{ Education } \\
\hline Primary & 18 & $6(4-7)$ & $8(6-10)$ & $<0.001$ \\
\hline Secondary & 22 & $4(2-6)$ & $9(4-10)$ & $<0.001$ \\
\hline University & 13 & $6(2-7)$ & $9(2-10)$ & 0.003 \\
\hline \multicolumn{5}{|l|}{ Smoking } \\
\hline Smoker & 15 & $4(2-6)$ & $9(2-10)$ & 0.001 \\
\hline Nonsmoker & 38 & $6(2-7)$ & $8(4-10)$ & $<0.001$ \\
\hline
\end{tabular}

*: Obtained from Wilcoxon signed rank test 
Physical and psychological domains of the participants as well improved after sessions overall and in all the subgroups (Table 3). However, in social relations and environmental domains although the improvements were found significant when evaluated overall; females, primary and university graduates did not reveal a significant improvements in social relations domain ( $p=0.53, p=0.56$ and $p=0.371$ respectively) whereas in environmental domain males, smokers and participants regarding their education levels did not reveal significant improvements $(p=0.148, p=0.148, p=0.148$, $p=0.071$ and $p=1.0$ respectively) (Table 4 ).

Table 3: Changes in the scores of physical and psychological domains before and after the WCT applications

\begin{tabular}{|c|c|c|c|c|c|c|c|}
\hline \multirow[b]{2}{*}{ Overall } & \multirow[b]{2}{*}{$\begin{array}{c}n \\
53\end{array}$} & \multicolumn{2}{|c|}{ Physical domain } & \multirow[b]{2}{*}{$\begin{array}{c}\mathrm{P}^{*} \\
<\mathbf{0 . 0 0 1}\end{array}$} & \multicolumn{2}{|c|}{ Psychological domain } & \multirow[b]{2}{*}{$\begin{array}{c}\mathrm{P}^{*} \\
<\mathbf{0 . 0 0 1}\end{array}$} \\
\hline & & $\begin{array}{c}\text { Pre-test } \\
\text { Median } \\
\text { (min-max) } \\
12(5-16)\end{array}$ & $\begin{array}{c}\text { Post-test } \\
\text { Median } \\
\text { (min-max) } \\
17(9-19)\end{array}$ & & $\begin{array}{c}\text { Pre-test } \\
\text { Median } \\
\text { (min-max) } \\
13(9-17)\end{array}$ & $\begin{array}{c}\text { Post-test } \\
\text { Median } \\
(\min -\max ) \\
16(9-20)\end{array}$ & \\
\hline \multicolumn{8}{|l|}{ Gender } \\
\hline Male & 27 & $10(7-16)$ & $17(9-19)$ & $<0.001$ & $11(9-17)$ & $16(9-20)$ & $<0.001$ \\
\hline Female & 26 & $13(5-15)$ & $16(9-19)$ & $<0.001$ & $13(9-17)$ & $15(11-17)$ & $<0.001$ \\
\hline \multicolumn{8}{|l|}{ Education } \\
\hline Primary & 18 & $12(8-15)$ & $16(12-19)$ & $<0.001$ & $13(10-17)$ & $15(13-17)$ & $<0.001$ \\
\hline Secondary & 22 & $9(7-14)$ & $17(9-19)$ & $<0.001$ & $11(9-16)$ & $16(9-19)$ & $<0.001$ \\
\hline University & 13 & $13\left(5^{-16}\right)$ & $17(9-19)$ & 0.002 & $13(9-17)$ & $17(11-20)$ & 0.002 \\
\hline \multicolumn{8}{|l|}{ Smoking } \\
\hline Smoker & 15 & $10(7-14)$ & $17(9-19)$ & 0.001 & $11(9-16)$ & $15(11-20)$ & 0.001 \\
\hline Nonsmoker & 38 & $12\left(5^{-16}\right)$ & $16(9-19)$ & $<0.001$ & $9(13-17)$ & $15(11-20)$ & $<0.001$ \\
\hline
\end{tabular}

*: Obtained from Wilcoxon signed rank test

Regarding the subgroups; males showed a better improvement in all $(p<0.001)$ but the environment domain. In this domain there was not a significant difference before and after WCT in men $(p=0.148)$ whereas female subjects improved $(p=0.036)$.

With regards to education, participants who were graduated from secondary schools demonstrated the best improvements in four domains of the HRQOL scores $(p<0.001$ in general health, physical and psychological domains, $p=0.005$ in social relations domain). However, their improvement in the environment domain was not significant $(p=0.071)$. The changes in the HRQOL scores of the participants with university degree were significant exclusively in general health, physical and psychological domains ( $p=0.003, p=0.002$ and $p=0.002$ respectively) whereas no significant improvement was seen in social relations and environment domains ( $p=0.371$ and $p=1.0$ respectively). 
Compared with smokers, non-smokers showed significant improvements in HRQOL scores in all domains $(p<0.001$ in general health, physical and psychological domains, $p=0.005$ in social relations and $p=0.036$ in environment domains) while smokers showed significant improvements only in general health, physical and psychological health. $(p=0.001)$. None of the participants reported any adverse events during or after WCT sessions.

Table 4: Changes in the scores of social relations and environmental domains before and after the WCT applications

\begin{tabular}{|c|c|c|c|c|c|c|c|}
\hline \multirow[b]{2}{*}{ Overall } & \multirow[b]{2}{*}{$\begin{array}{c}n \\
53\end{array}$} & \multicolumn{2}{|c|}{ Social relations domain } & \multirow[b]{2}{*}{$\begin{array}{c}\mathrm{P}^{*} \\
<\mathbf{0 . 0 0 1}\end{array}$} & \multicolumn{2}{|c|}{ Environmental domain } & \multirow[b]{2}{*}{$\begin{array}{c}\mathrm{P}^{*} \\
\text { 0.005 }\end{array}$} \\
\hline & & $\begin{array}{c}\text { Pre-test } \\
\text { Median } \\
(\text { min-max) } \\
15(9-20) \\
\end{array}$ & $\begin{array}{c}\text { Post-test } \\
\text { Median } \\
(\text { min-max) } \\
16(9-20)\end{array}$ & & \begin{tabular}{|c|} 
Pre-test \\
Median \\
$($ min-max $)$ \\
$15(9-20)$ \\
\end{tabular} & \begin{tabular}{|c|} 
Post-test \\
Median \\
$($ min-max $)$ \\
$16(9-20)$ \\
\end{tabular} & \\
\hline \multicolumn{8}{|l|}{ Gender } \\
\hline Male & 27 & $15(12-20)$ & $16(12-20)$ & 0.002 & $15(12-20)$ & $16(12-20)$ & 0.148 \\
\hline Female & 26 & $14(9-16)$ & $14(9-16)$ & 0.053 & $14(9-16)$ & $14(9-16)$ & 0.036 \\
\hline \multicolumn{8}{|l|}{ Education } \\
\hline Primary & 18 & $15(9-16)$ & $15(9-19)$ & 0.056 & $15(9-16)$ & $15(9-19)$ & 0.148 \\
\hline Secondary & 22 & $13(9-16)$ & $16(9-19)$ & 0.005 & $13(9-16)$ & $16(9-19)$ & 0.071 \\
\hline University & 13 & $12(15-20)$ & $12(15-20)$ & 0.371 & $12(15-20)$ & $12(15-20)$ & 1.000 \\
\hline \multicolumn{8}{|l|}{ Smoking } \\
\hline Smoker & 15 & $13(11-16)$ & $16(12-19)$ & 0.020 & $13(11-16)$ & $16(12-19)$ & 0.148 \\
\hline Nonsmoker & 38 & $15(9-20)$ & $15(9-20)$ & 0.005 & $15(9-20)$ & $15(9-20)$ & 0.036 \\
\hline
\end{tabular}

*: Obtained from Wilcoxon signed rank test

\section{Discussion}

In the current study which was conducted on healthy individuals we investigated the efficacy of WCT on quality of life by evaluating WHOQOL-BREF-TR. All scores of HRQOL in 4 domains and general health improved significantly after the WCT applications compared to initial values.

When we evaluated the scores through facets incorporated within domains it came out that the participants reported best improvements in the following three: Energy and fatigue, pain and discomfort and sleep and rest. A great majority of the participants have emphasized that they had better sleep quality, felt more energetic and experienced less pain following the applications. Among these the pain reducing property of WCT is well known since it has been shown in various studies that WCT is effective in pain management related to different disorders. ${ }^{1-3}$

Among the results of our study it was observed that even the HRQOL scores of the environment domain improved. This surprising finding might be due to the improvement in psychological wellbeing so that the participants felt happier in their 
surroundings. However, subgroups statistics revealed that environmental scores of post treatment assessments were significantly higher exclusively in female participants, whereas no improvement was seen in male subgroup. This finding suggests that a gender related difference may be present in the benefit of WCT in environment scores.

There are theories about therapeutic effects of WCT that haven't formed a consensus. Nonetheless, detoxificating effects of WCT have been emphasized since ancient times. During the time of Hippocrates, who developed the humoral theory, bloodletting was known to have balancing properties. ${ }^{10}$ Salah M. El Sayed et al. as well suggested that several pathologies may be healed by removing noxious substances from blood, lymph and intercellular area via WCT. ${ }^{11}$

Karabük province where the study was conducted is one of the main industrial cities in Turkey and a significant proportion of the city population is employed in iron and steel industry. ${ }^{12}$ Environmental pollution due to industrial activities in the city increases exposure to many toxic substances and particularly heavy metal exposure is a great risk not only in steel workers but also in general population. There are studies reporting WCT was effective in removing heavy metals from the body. ${ }^{13}$ We suggest that detoxifying effect of WCT might be the main reason for the improvement of the HRQOL scores in our study. Besides, WCT has immune modulatory, anti-oxidant and free radical scavenging properties as well. ${ }^{14}$ These properties also might have contributed to the wellness of the participants.

In the current literature we were able to find only one study from Saudi Arabia which evaluated the effect of WCT on HRQOL. ${ }^{15}$ As a difference, that study was conducted on patients who had chronic medical conditions. However, results were supporting our thesis as significant improvements were seen in the mean scores of the all of the physical, psychological, social and environmental domains after cupping compared with initial scores. But, while women demonstrated significantly better scores in almost all 4 HRQOL domains after WCT in that study, in our study HRQOL scores of men were more significant. We also came up with discrete results according to education as patients with a University degree had better scores in that study while in our study they had the lowest scores. Another subgroup, non-smokers demonstrated better scores of HRQOL when compared to smokers in both studies.

Absence of a control group is the main limitation in our study. Because implementation of a convincing sham cupping method remains to be a challenge. This is even harder in WCT. To imitate dry cupping, some authors suggested using a sham cupping device which applies little or no negative pressure due to a hole on its surface. ${ }^{16}$ Even this method is open to argument and has been criticized for not being a proper sham application. ${ }^{17}$ Therefore we opted a self-controlled study design rather than including a sham control group.

Our results suggest that quality of life may be improved in healthy adults by WCT. These kinds of studies may spark the interest to complementary therapies and give way to further research in larger scales.

Declaration of Interest: The authors declare no conflict of interest. 


\section{References}

1. Benli AR, Sunay D. Changing Efficacy of Wet Cupping Therapy in Migraine with Lunar Phase: A Self-Controlled Interventional Study. Med Sci Monit, 2017; 23: 6162-7

2. Arslan M, Gokgoz N, Dane S. The effect of traditional wet cupping on shoulder pain and neck pain: A pilot study. Complementary Therapies in Clinical Practice, 2016; 23:30-3

3. Kim JI, Kim TH, Lee MS et al. Evaluation of wet-cupping therapy for persistent non-specific low back pain: a randomised, waiting-list controlled, open-label, parallel-group pilot trial. Trials 2011; $12: 146$

4. Al Bedah AMN, Mohamed KM, Posadzki P et al. Evaluation of Wet Cupping Therapy: Systematic Review of Randomized Clinical. The Journal of Alternative and Complementary Medicine, 2016; 22.10: 768-77.

5. Refaat B, El-Shemi AG, Ebid AA, Ashshi A, \& BaSalamah MA. Islamic wet cupping and risk factors of cardiovascular diseases: effects on blood pressure, metabolic profile and serum electrolytes in healthy young adult men. Altern Integ Med, 2014;3(1): 151.

6. Khalil AM, Khaled MA and Shaqqour HM. Investigation of Selected Immunocytogenetic Effects of Wet Cupping in Healthy Men. Spatula DD. 2013; 3(2):51-7

7. Whoqol Group. Development of the World Health Organization WHOQOL-BREF quality of life assessment. Psychological medicine, 1998; 28(3), 551-8.

8. Eser E, Fidaner H, Fidaner C, Eser SY, Elbi H \& Göker E. WHOQOL-BREF TR: a suitable instrument for the assessment of quality of life for use in the health care settings in Turkey. Quality of Life Research, 1999; 647.

9. Minitab 17 Statistical Software [Computer software]. State College, PA: Minitab, Inc. 2010. (www.minitab.com).

10. Ahmedi M, Siddiqui MR. The value of wet cupping as a therapy in modern medicine - An Islamic Perspective. Web med Central Alternative Medicine 2014;5(12):4785

11. El Sayed S, Mahmoud H and Nabo M. Methods of wet cupping therapy (Al-Hijamah): in light of modern medicine and prophetic medicine. Alternative \& Integrative Medicine, 2013: 1-16.

12. Aydın F. The effect of Kar-Demir on Karabük city population. Procedia-Social and Behavioral Sciences, 2011; 19: 494-8.

13. Umar NK, Tursunbadalov S, Surgun S, Welcome OM, Dane S. The effects of wet cupping therapy on the blood levels of some heavy metals: a pilot study. Journal of acupuncture and meridian studies 2018; 11.6: 375-9.

14. Ahmed SM, Madbouly NH, Maklad SS \& Abu-Shady EA. Immunomodulatory effects of bloodletting cupping therapy in patients with rheumatoid arthritis. The Egyptian journal of immunology, 2005; 12.2: 39-51.

15. Al Jaouni SK, El-Fiky EA, Mourad SA et al. The effect of wet cupping on quality of life of adult patients with chronic medical conditions in King Abdulaziz University Hospital. Saudi medical journal, 2017; 38.1: 53 .

16. Lee MS, Kim JI, Kong JC, Lee DH \& Shin BC. Developing and validating a sham cupping device. Acupuncture in Medicine 2010; 28(4): 200-4.

17. Yıldız S, Duruhan S, Çelik N, Tuncay MS, Uyar M, \& Bayar B. Sham kupa terapisi cihazı hakkında bir eleștiri. Integr Tip Derg 2014;2.2:1-5. 